\title{
THE RELEVANCE OF JALALUDDIN RUMI'S SUFISM EDUCATION CONCEPT TO CHARACTER EDUCATION IN THE DIGITAL ERA
}

\author{
Arizul Suwar $^{(1)}$, Tb. Endayani ${ }^{(2)}$ \\ ${ }^{1,2}$ STAIN Teungku Dirundeng Meulaboh \\ Email : Endayany@gmail.com
}

\begin{abstract}
This study aims to determine the concept of Sufism education according to Jalaluddin Rumi, and its relevance to character education in the digital era. The method used in this research is library research. Primary sources are Jalaluddin Rumi works, secondary sources are books and works that are relevant to the discussion of the concept of spiritual education. The data analysis technique uses content analysis method. The results of the discussion of this study indicate that education according to Jalaluddin Rumi is the ability to transcend everything that is born (visible) with the aim of obtaining the inner meaning behind it, related to character education. Rumi emphasizes education in the realm of spirituality (heart) because character is a reflection of the human heart. Facing a digital era marked by being fast and instantaneous, Rumi warns all of us not to forget the process, because something valuable can only be produced from a maximum process. On the other hand, Rumi also emphasized the importance of awareness, this is because character is marked by "one's attitude towards others", awareness here means being aware that other people are also human as they are God's creatures, meaning that they must be able to respect other people without any restrictions of identity.
\end{abstract}

Keywords: Sufism Education, Jalaluddin Rumi, character education, the Digital Era

\begin{abstract}
ABSTRAK
Penelitian ini bertujuan untuk mengetahui: Konsep pendidikan tasawuf menurut Jalaluddin Rumi, dan Relevansinya terhadap pendidikan karakter di era digital. Metode yang digunakan dalam penelitian ini adalah penelitian kepustakaan (library research). Sumber primer berupa karya langsung dari Jalaluddin Rumi, sumber sekundernya adalah buku dan karya yang relevan dengan pembahasan konsep pendidikan spiritual. Adapun teknis analisis data menggunakan metode analisis isi (content analysis). Hasil dari pembahasan penelitian ini menunjukan bahwa Pendidikan menurut Jalaluddin Rumi adalah kemampuan untuk melampaui segala yang lahir (nampak) dengan tujuan memperoleh makna batin di baliknya, berkaitan dengan pendidikan karakter Rumi menekankan pendidikan pada ranah spiritualitas (hati) karena karakter adalah cerminan dari hati manusia. Menghadapi era digital yang ditandai dengan serba cepat dan instant, Rumi memperingatkan kita semua agar tidak melupakan proses, karena sesuatu yang bernilai hanya dapat dihasilkan dari proses yang maksimal. Di sisi lain, Rumi juga menekankan pentingnya kesadaran, hal ini karena karakter ditandai dengan "sikap seseorang terhadap orang lain",
\end{abstract}


kesadaran di sini berarti sadar bahwa orang lain juga manusia sebagaimana dirinya sama- sama makhluk Tuhan, artinya harus bisa menghargai orang lain tanpa sekat- sekat identitasnya.

Kata kunci : Pendidikan tasawuf, Jalaluddin Rumi, pendidikan Karakter, Era digital

\section{INTRODUCTION}

Education is a process of behavior transformation, a process from potential to actual, from not knowing to knowing, from children to maturity. In Indonesia, the purpose of education as described in Law Number 20 of 2003 concerning the National Education System states that "National education has the function of developing capabilities and shaping dignified national character and civilization in the context of educating the nation's life, aimed at developing the potential of students to become human beings. who have faith and devotion to God Almighty, have noble character, are healthy, knowledgeable, competent, creative, independent and become democratic and responsible citizens. "Education in Indonesia experiences various challenges, especially with regard to the character building of students, character education. which should have started from the cultivation of spiritual values, but in reality our education still focuses on the cognitive only.

Sufism education emphasizes the process of purification of the soul (tazkiyatun nafs), purifying the heart from all its impurities such as hatred, envy, revenge, arrogance, and so on. Sufism education is a spiritual education that aims to realize the commandments of Allah SWT :

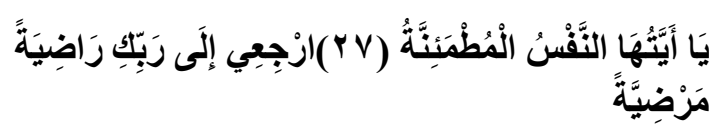

Meaning: Hii.. quiet soul, Go back to your Lord with a satisfied heart that is pleased with Him. (Surah Al-Fajr: verses 27-28).
Humans are spiritual beings, besides having a physical aspect (body), they also have a mental aspect (heart), and it should be noted that a human being is supported by his inner aspect (heart) so that if the human heart is clean from defilements such as hate, arrogant, humiliating other creatures, then it will be seen in the dimensions of his body in the form of his daily actions or in other words in the form of his character, on the other hand, if the human heart is filled with impurities like the aforementioned then it will also be seen in his daily character. A person's character can never be separated from his inner dimension, a person's character that is reflected in his daily words and actions is a result or effect of his mental condition, the condition of his heart. If a person's inner dimension is filled with compassion there is no way he will spread hatred, if the heart has been filled with the awareness that he is a creature of God, he certainly will not look down on other people or other creatures.

Character education aims to make students as the nation's successor have good morals and morals, to create a fair, safe and prosperous life as a nation. Education which continues to change from time to time along with the times, entering the digital era as it is today, the development of students is also very different, technological advances and the ease of carrying out various activities on the network risk alienating students from noble values and noble characters. Today the government has introduced a government program called Strengthening Character Education (PPK), KDP is an attempt to cultivate character education in schools. The KDP program aims to promote quality and moral education that is evenly distributed 
throughout the nation. Issuance of Presidential Regulation number 87 article 2 of 2017 concerning Strengthening Character Education (PPK), PPK has the following objectives:

1. Build and equip students as Indonesia's golden generation in 2045 with the spirit of Pancasila and good character education to face the dynamics of change in the future.

2. Developing a national education platform that places character education as the main soul in the delivery of education for students with the support of public involvement through formal, non-formal, and informal education by taking into account the diversity of Indonesian cultures.

3. Revitalizing and strengthening the potential and competence of educators, education staff, students, society, and the family environment in implementing PPK (http://www.setkab.go.id/wpcontent/upload/2017/09/Perpres No 87 tahun 2017).

Character education cannot be separated from spirituality. In Islamic scholarship, the focus of studying spirituality is Sufism, the perpetrators or practicing Sufism are often referred to as Sufi. In this paper, the author wants to find and offer the concept of Sufism education in the perspective of Jalaluddin Rumi and how it is relevant to character education in today's digital era.

Research question

Based on the background of the problems above, the problem formulations in this discussion are:

1. How is Jalaluddin Rumi's perspective on Sufism education?

2. How is the relevance of Jalaluddin Rumi's perspective of Sufism education to character education in the digital era?
Research Purpose

Based on the problem formulation above, the research objectives are:

1. To know the perspective of Jalaluddin Rumi's Sufism education.

2. To explain the relevance of Sufism education from Jalaluddin Rumi's perspective on character education in the digital era.

\section{RESEARCH METHOD}

The research used in this study is library research, which is research conducted by searching for data or information through reading reference books, scientific journals, and publication materials available in libraries and on the internet related to the topic of discussion. . Methodologically, the library research belongs to the category of qualitative research, that the research whose data is in the form of documents, records of past events which can be in the form of writings, pictures, or monumental works of a person. The data obtained in this study can be grouped into two, namely:

1. Primary data, namely data in the form of direct work from Jalaluddin Rumi, namely:

a) Matsnawi ma'nawi, this work consists of six volumes of books which outline contain poetry verses. Rumi uses various types of ways in expressing his thoughts, in this work there are stories, anecdotes, etc., but all the contents touch on aspects of spiritual learning and thinking.

b) Fihi ma Fihi, this book contains a collection of lecture material, reflections and comments that discuss issues around morals and Sufism which are complemented by interpretations of the Qur'an and Hadith. 
2. Secondary data, namely works written by other people about Jalaluddin Rumi's thoughts as well as various works that are relevant to the discussion of the concept of spiritual education.

The data that has been collected in this study will then be analyzed using the Content Analysis method. Definition of Content Analysis is a research methodology that utilizes a set of procedures to draw correct conclusions from a book or document (https://www.dosenpendidikan.co.id/analisis -isi/). With this analysis technique the writer will analyze the meaning or content contained in the data source and its relation to Sufism education.

\section{RESULT AND DISCUSSION}

a. Short Biography of Jalaluddin Rumi

Jalaluddin Rumi, his full name is Jalaluddin Muhammad bin Husin al-Khathbi. He was born on September 30, 1207 A.D. in Balkhi (Persia), a city now located in northern Afghanistan (Jalaluddin Rumi, 2001). Jalaluddin Rumi got his takhallus or nickname Rumi because he spent most of his life in Konya, Turkey, which at that time was part of the Eastern Roman Empire.

Jalaluddin Rumi's father was named Bahauddin Walad, often also called Baha 'Walad, his mother was named Mumina Khatun (Miswari, 2020). Jalaluddin Rumi was still quite young when he started studying the exoretic sciences. He studied various fields of science including Arabic grammar, poetry, the Koran, fiqh, ushul fiqh, tafsir, history, theology, logic, philosophy, mathematics and astronomy. By the time his father died in $1231 \mathrm{AD}$, he had mastered all these sciences. At the age of 24, Jalaluddin Rumi was asked to replace his father's position as an expert in Islamic jurisprudence, since then he has been driven towards Sufism. However, formally he had only just started life as a Sufi when Burhanuddin Tirmidzi, his father's favorite student, came to Konya in 1240 AD, it was under his guidance that Rumi underwent spiritual disciplines .

Jalaluddin Rumi's life as a Sufi cannot be separated from a mysterious Sufi named Syams Tabrizi, he is the one who causes Rumi to change from a calm jurist to a drunken lover (divine love). For about one or two years, Syam Tabrizi always accompanied Rumi, when suddenly Syam Tabrizi left Konya. In the end, Rumi was worried. Then Rumi tried to persuade him to come back and succeeded. However, not long after, around $1247 \mathrm{AD}$, he disappeared again. According to some sources, he was killed by one of his "jealous" admirers. However, nevertheless, she still lives in Rumi's heart and inspires some of her ghazals (love poems), who keep chanting his name .

Jalaluddin Rumi died on 17 December $1273 \mathrm{AD}$, when he felt the last pain, he said to his friends. "In this world I feel two closeness. One to the body and one to you, because of God's grace, I have to get away from the solitude and worldly life, my closeness to you will remain" (Jaluddin Rumi, 2001).

b. The works of Jalaluddin Rumi

Jalaluddin Rumi is known as a Sufi and also a great Persian poet, interestingly Rumi uses poetry, prose and poetry as a medium for spiritual education (tarbiyah ruhiyah). Jalaluddin Rumi did not write books in conventional form as others did. Besides being recorded by his students when Rumi delivered them orally, his poetry, prose and verses were also recorded by his followers from their memory or from Rumi's own notes after his death.

Each of Rumi's expressions, whether they are in the form of poetry, prose, or poetry, constitutes an education to develop 
human spiritual intelligence. For Rumi, someone who has spiritual intelligence is a pious servant of Allah. The main works of Jalaluddin Rumi are:

1) Matsnawi- Ma'nawi

This book is Rumi's main work. This work consists of six volumes containing 25,000 verses of poetry. Rumi uses various kinds of ways in expressing his thoughts, in this work there are stories, anecdotes, etc., but all the contents touch on aspects of spiritual learning and thinking (Jalaluddin Rumi, 2001).

2) Diwan Syams- i Tabriz

It is called Diwan Syamsi Tabriz because one third of the total 3,229 ghazals in it mention the name Shamsuddin Tabriz. Diwan Syamsi Tabriz can be said to be Rumi's "love song" to his teacher, Syamsuddin Tabriz (Jaluluddin Rumi, 2001).

3) Fihi ma Fihi

This book is the work of Jalaluddin Rumi in his presentation in the form of prose. The main purpose of this book Fihi ma Fihi is spiritual training for human beings so that they follow what God, the god of the universe and the universe wants (Jalaluddin Rumi, 2014).

4) Ruba'iyyat

Ruba'iyyat Is a work of Jalaluddin Rumi in the form of poetry delivered in the form of quatrines (4-line verse). This work consists of 3,318 verses of poetry.

5) Al- Majalis- as- Sab'ah

Al-Majalis-as-Sab'ah is a collection of advice and sermons by Jalaluddin Rumi that he delivered from the pulpits which is the result of Rumi's life adventure that met him with the teacher, Syamsuddin Tabriz (Jalaluddin Rumi, 2014).

c. Character education

Education is an aid to awaken, grow, enable and empower students of their natural potential (Iswan dan Herwina, 2018). The character comes from the Greek charassein which means to mark, which is to mark or engrave, which focuses how to apply the value of goodness in the form of actions or behaviors (Ngainun Naim, 2012). In the Indonesian Dictionary, the word "character" is defined as habits, psychic qualities, morals or character that distinguish one person from another, and character (https://kbbi.web.id/karakter). Characters are values related to the Almighty God, oneself, fellow human beings, the environment and the nation that are embodied in thoughts, attitudes, feelings, words, and deeds based on religious norms, laws, manners, culture, and customs (Fitri, 2005).

Character education is everything that the teacher does, which is able to influence the character of students (Dini Palupi Putri, 2018). Character education is also called character education, as education for the value of human morality that is realized and carried out in real action. Here there is an element of the process of forming this value and a conscious attitude towards knowing why that value is exercised. All the values of morality that are realized and carried out are aimed at helping humans to become more complete humans. These values help people to live better together with other people and their world to achieve perfection (Masnur Muslich, 2011).The purpose of character education is to create intelligent, creative, moral and positive people so that they are able to manage and take part in building a dignified nation (http://osf.io/06v8e/download/?format=pdf). Character education in Islam is also referred to as moral education, morality is a trait inherent in a person's soul which is reflected in his daily actions, Imam al-Ghazali said that morals are traits embedded in the soul that cause various actions easily and easily without the need thoughts and considerations (al-Ghazali, t.t.). 


\section{RESEARCH DISCUSSION}

\section{Sufism Education Concept of Jalaluddin Rumi's Perspective}

Education according to Rumi is beyond all external forms and acquires the meaning (value) behind it all. just as man is made up of body and soul, born and inward, as well as all that happens to man, whether it be in the form of joy, sorrow, weeping or laughter, happiness or suffering - it is all a form of God's education to man. Rumi wants to invite all of us not only to be glued to something that is visible (born) but also to get the meaning behind the visible (born). Rumi's poet:

Don't be like the devil,

Only saw Adam as water and mud.

He forgot that behind the mud,

Hundreds of thousands of beautiful

gardens grow (Haidar Bagir, 2015).

In these verses, Rumi wants to show how to judge something be it events, other people, or whatever, it is not only limited to its outward appearance, its physicality, but must reach the deepest core of all of it. The devil was deceived because he only saw Adam only as he was physically outward, "don't be like the devil, only seeing Adam as water and mud", so that the thought "what is the meaning of water mixed with mud", Devil was unable to grasp the meaning of what he saw, he forgot behind the mud, grew hundreds thousands of beautiful gardens. Obtaining the inner meaning of everything is what is called education according to Jalaluddin Rumi. The acquisition of this inner meaning will later lead someone to know Allah SWT, this is the goal of education for Rumi. In his poetry Rumi said:

What appears from the earth is the dust,

but behind the dust are the manifest qualities of God. the inner dimension was a lump of gold, while the outer dimension was a lump of rock

(https://matahati.news/2019/12/11/nga ji-ala-jallaludin-rumi/).

Sufism education begins by cleansing the heart of despicable traits, such as jealousy, envy, arrogance, selfishness, and so on. Regarding liver disease that must be cleaned, Rumi teaches a lesson through a story:

In a city there is a man planting a thorn tree in the middle of the road. The mayor had warned him to cut the thorny tree. Whenever he was reminded, the person always said that he would cut it tomorrow. But until the man was old, the tree had not been cut. Over time, the thorn tree grew bigger. It covered all parts of the road. The thorns not only injure the passer-by, they also injure their owner. The person is very old. He became so weak that he could no longer cut the tree he had planted himself (https://www.wattpad.com/162231064 -kisah-tentang-rumi-pohon-berduri-ditengah-jalan).

At the end of the story, Rumi gave his advice, In this life, you have planted many thorn trees in your hearts. The thorns stabbed not only others but also yourself. Cut all the thorns now before you lose any strength. What Rumi meant by a thorny tree in the heart were diseases of the liver. As the age increases, so does the strength. There is no better time to cut down that thorny tree in our hearts than right now.

Jalaluddin Rumi in his education concept emphasizes the importance of process, meaning that everything needs to be a process, nothing is completely instant. Especially if it is related to character or morals, there is no instant story here, you still have to go through a long process because the character is the result of a habit that is continuously practiced. 
On the other hand, Jalaluddin Rumi also emphasized the importance of what is known as awareness. Consciousness for Rumi is the ability to grasp the meaning (implied) of all forms (express). Jalaluddin Rumi illustrates this point:

"Without thought, forms are immobile and die. So, whoever looks only at form, means he is also dead, he is unable to grasp meaning. He was an immature child, even though in his form he was a hundred year old sheikh" (Jalaluddin Rumi, 2018).

From this awareness the beginning of the idea of universal love taught by Jalaluddin Rumi. for example when a person realizes that he is a creature of God, then there is no way he will undermine other people, seize the rights of others, because he is aware that he and others also come from the same, namely the creation of Allah SWT, when someone realizes that everything is happened with the permission of Allah and with all His Rahman and Rahim, of course he will not prejudice, will not give up hope, because he realizes that it all contains lessons and goodness for himself, Rumi calls this as "able to transcend outer forms and achieve the inner meaning of it all ". It should be emphasized that knowing is not the same as being aware, knowing lies in the realm of reason (cognitive), while being aware comes from the heart (spiritual), people who know are not necessarily aware, it is possible for everyone to know that littering is not a good action but that not necessarily that person has the awareness to practice it.

\section{The Relevance of Jalaluddin Rumi's Perspective Sufism Education on Character Education in the Digital Age}

An action that is repeated will become a habit, a habit that is continuously maintained will become a character. It should be remembered that action is not born from emptiness, it is born from one's way of thinking, a way of thinking emerges from the human heart (spirituality). If someone's heart is filled with hatred, it will lead to thoughts that want to get rid of the object (other person), this will be seen in daily actions in the form of inciting, playing one against one another, spreading hoaxes. If this action is repeated over and over again, it will become a character filled with hatred, dishonesty, does not accept suggestions or advice.

Character education cannot be separated from heart education (spiritual), heart education is like the foundation of a house, while character is like a wall or a wall, the condition of the walls is completely dependent on the foundation, without a solid foundation, no matter how hard it is to strengthen the walls, it cannot be done.

The digital era is where everyone can enjoy convenience in various aspects of life (http://ejournal.unp.ac.id./index.php/etech/article/download/101344/100536). The digital era appears as an opportunity as well as a challenge for the world of education in Indonesia, an opportunity because it is able to present something quite efficiently, makes long distances feel close, and saves more costs, the challenges include because technology can make people spoiled, their desires are instantaneous, challenges the most important thing for the world of education is to be able to keep students away from noble values in society, make students asocial, prioritizing virtual life rather than real life, wanting to gain knowledge instantly, which ultimately "gets knowledge but forgets morals".

In the digital era, gaining knowledge is not a difficult thing, thousands of reading materials can be contained in just one gadget, the increasingly heavy information is no longer limited by space and time, everything 
becomes easy. But behind it all the degradation of noble values in society and the noble character of students can be lost, this is why character education is needed in this era. Reading these developments, the government introduced a program called Strengthening Character Education. It is an attempt to cultivate character education in schools. The program aims to promote quality and moral education that is evenly distributed throughout the nation.

Related to character education, Jalaluddin Rumi, a 13th century Persian Sufi, has explained the importance of paying attention to spirituality, as in general Sufis, Jalaluddin Rumi also pays very special attention to the human heart, because what distinguishes the good and the bad is the heart. Education for Rumi begins by cleaning the heart of despicable traits, such as jealousy, jealousy, arrogance, selfishness, and so on. If the human heart is clean then all forms of action will certainly be colored by goodness and beauty, which will then produce a noble character.

The digital era, which is marked by instantaneous offers, has poisoned the thinking of the younger generation to "we want, we can" so that they forget the process that must be gone through, so it's no wonder that every day we see it on social media continuously popping up instant "experts" who are able to talk about everything from politics to religion, causing chaos (chaos) in the life of religion, nation and state. Relateted to the something instant, Jalaluddin Rumi has warned us that everything must go through a process, nothing is instantaneous, especially if it is related to character building or character education. Basically, what is called a process is certainly unpleasant, especially for those who have been lying in the "comfort zone" of practicality for a long time, but without the process how can a satisfactory result be obtained? We must realize that this unpleasant process is part of the struggle to actualize the potential that is within us. We must be aware that something we perceive as "unpleasant / painful", does not mean it is useless, or not beneficial, we have to realize that behind everything there is an inner meaning, that is what we should be aware of, just look at the medicine, most of us will say it is "bad" but is it not beneficial ?, through that medicine God gave healing. Pay attention to the baby who cries when he is weaned, for the baby that time is a moment that makes him very "suffer" because he does not get breast milk as usual, but in that way a baby can actually be free from its bondage to breast milk. This is a guide so that every human being is able to derive the inner meaning of everything, Rumi describes this beautifully in a poet:

without the cry of the sky, how would the flowers in the garden bloom.

If you feel disturbed at every friction, how will you become a shiny mirror? if the bread has not been split, how can it be eaten?

If the citron fruit has not been crushed, how can it be a medicine for the sick? (Jalaluddin Rumi, 2019).

Furthermore, it also found the reality that there is an imbalance between knowledge and practice. A person may know many theories about science, but that is not necessarily reflected in the character of that person. Things like this arise because of the imbalance between intelligence (cognitive) with spiritual awareness. Jalaluddin Rumi really understands the importance of awareness, so that the portion of Rumi's attention to consciousness is enormous. This can be seen in the various teachings conveyed through symbols but full of meaning, this meaning is what Rumi wants to understand. As seen in one of his verses: 
What appears from the earth is the dust, but behind the dust are the manifest qualities of God (https://matahati.news/2019/12/11/nga ji-ala-jallaludin-rumi/).

In these verses, it can be seen that something that is caught by our senses has a meaning behind it, this meaning that we must be aware of which can then be a lesson in living life.

Character is a reflection of a person's spirituality, if you want to build a noble character, the first thing to pay attention to is to educate the heart or spiritually through continuous purification efforts. Cleansing the heart for Rumi begins with an awareness that we as humans are not free from mistakes and sins, in other words humans are filled with limitations. Because humans are limited, the only thing they can hope for is God. Rumi's poet:

Whoever acknowledges and informs his weakness,

he accelerates himself on the path to perfection.

will not move forward towards the Almighty,

he who considers himself perfect.

there is no disease worse than considering yourself perfect (Matsnawi, 2019).

When a person has been able to realize and acknowledge his weaknesses, then someone will find mutual respect in his heart, he will see that he and others are equal in God's side, then the awareness not to humiliate, not feel self-righteous will arise, and this will be reflected in behavior that does not discredit or differentiate between people based on ethnicity, religion, race and between groups.

Furthermore, the awareness that other people are also humans who are equal to oneself will bring up a way of assessment or perspective that is not limited to one's identity alone, not limited to religious symbols, a person will be able to find the innermost core of man, namely his heart or mind. Rumi explained:

If form is the essence that makes him human,

Ahmad and Abu Jahl will be the same.

One painting on the wall resembles a human,

But look what the empty form lacks.

It is the life that is not in the shadows of man. Come on, look for the pearl that the shadow will never find (Matsnawi, 2019).

If someone already has a perspective that can transcend their external identities, of course actions such as bullying, demeaning, and racial sentiments, will not occur.

\section{CONCLUSION}

The digital era as an inevitable cycle of times has had a major influence in the world of education. The influence of technology in all fields presents an opportunity as well as a challenge, especially with regard to the character of the nation's next generation. Strengthening character has become a major concern for education today.

According to Jalaluddin Rumi, education is the ability to transcend everything that is born with the aim of obtaining the inner meaning behind it, related to character education. Rumi emphasizes education in the realm of spirituality (heart) because character is a reflection of the human heart. Facing a digital era marked by being fast and instantaneous, Rumi warns us all not to forget the process, because something valuable can only be produced from a maximum process. On the other hand, Rumi also emphasized the importance of awareness, this is because character is marked by "one's attitude towards others", 
Jurnal Sosial Humaniora Sigli (JSH)

p ISSN : 2615-3688

$e$ ISSN : 2716-0270

http://journal.unigha.ac.id/index.php/JSH

awareness here means being aware that other people are also human as they are God's creatures, meaning that they must be able to respect others without barriers of identity.

\section{BIBLIOGRAPHIES}

Al Ghazali. Ihya 'Ulum al Din. Indonesia : Dar Ihya al Kutub al- Arabi, t.t.

Departemen Pendidikan Nasional. UndangUndang No 20 Tahun 2003. Jakarta:

Depdiknas. 2003.

Dini Palupi Putri, Pendidikan Karakter Pada Anak Sekolah Dasar di Era Digital, AR-RIAYAH : Jurnal Pendidikan Dasar vol. 2, no. 1, 2018. Bengkulu: STAIN Curup. | p ISSN 2580-362X; e ISSN 2580-3611,

Dosen Pendidikan. Analisis Isi (online). https://www.dosenpendidikan.co.id/a nalisis-isi/

Sapitri, Eka Yulia. Pentingnya Pendidikan Karakter bagi Peserta Didik, 2020, online

http://osf.io/06v8e/download/?format $=$ pdf, diakses pada 15 November 2020 .

Fitri, Pendidikan Karakter Berbasis Nilai Dan Etika Disekolah. Yogyakarta: Ar- ruz Media, 2005.

Bagir, Haidar. Belajar Hidup Dari Rumi. Jakarta Selatan: Mizan, 2015.

https://kbbi.web.id/karakter, diakses pada 13-11-2020.

https://matahati.news/2019/12/11/ngaji-alajallaludin-rumi/ diakses pada tanggal 19- Oktober- 2020. https://matahati.news/2019/12/11/ngaji-alajallaludin-rumi/ diakses pada tanggal 19- Oktober- 2020.

https://www.wattpad.com/162231064-kisahtentang-rumi-pohon-berduri-ditengah-jalan, diakses pada tanggal 19- Mai- 2020.

Iswan dan Herwina, Prosiding Seminar Nasional Pendidikan Era Revolusi. "Membangun Sinergitas dalam Penguatan Pendidikan Karakter pada Era IR 4.0". Penguatan Pendidikan Karakter Perspektif Islam Dalam Era Millenial IR. 4.0. ISSN : 2621-6477. 21. Jakarta: Universitas Muhammadiyah. 2018.

Rumi, Jalaluddin. Fihi Ma Fihi "Manifestasi Cinta dan Kebijaksanaan Rumi". Yogyakarta: Mueeza, 2018.

Rumi, Jalaluddin. Matsnawi "Bait- bait Ilahi Untuk Pendidikan Ruhani”. Jakarta: Zaman, 2019.

Muslich, Masnur. Pendidikan Karakter. Jakarta: PT. Bumi Aksara, 2011.

Miswari. Senandung Cinta Penuh Makna: Analisa Filosofis Puisi Jalaluddin Rumi. Al- Mabhats: Jurnal Penelitian Sosial Agama, Vol. 3. No. 1, 2018.

Miswari. Tasawuf Terakhir. Yogyakarta: Zhahir Publishing. 2020.

Naim, Ngainun. Charakter Building. Jogjakarta: Ar-Ruzz Media, 2012.

Peraturan Presiden No 87 Pasal 2 Tahun 2017. Penguatan Pendidikan Karakter. (http://www.setkab.go.id/wpcontent/upload/2017/09/Perpres No 87 tahun 2017. ( Diakses 12 November 2020) 
Jurnal Sosial Humaniora Sigli (JSH)

p ISSN : 2615-3688

$e$ ISSN : 2716-0270

http://journal.unigha.ac.id/index.php/JSH

Rumi, Jalaluddin. Fihi Ma Fihi "Mengarungi Samudera Kebijaksanaan".

Yogyakarta: Forum. 2014.

Rumi, Jalaluddin. Matahari Diwan Syams Tabrizi. Yogyakarta: Forum. 2018.

Rumi, Jalaluddin. Yang Mengenal Dirinya yang Mengenal Tuhannya "Aforisme- Aforisme Sufistik
Jalaluddin Rumi”. Bandung: Pustaka Hidayah. 2001.

Syur'aini, Setiawati, Vevi Sunarti, Penanaman Nilai Karakter sebagai Upaya Mereduksi Dampak Negatif Era

Digital, http://ejournal.unp.ac.id./index.php/e tech/article/download/101344/10053 6, diakses pada 16 November 2020. 